\title{
Ensaiar a escrileiturartista na universidade
}

To rehearse the artistic-writreading in the university

Ester Maria Dreher Heuser ${ }^{i}$ Sandra Mara Corazzaii

\section{Resumo}

Universidade Federal do Rio Grande do Sul

Práticas, experimentamos e ensaiamos a leitura e a escritura na universidade. Acabando com a saturação do silogístico, introduzimos a dissonância textual. Convocando recursos sutis e o valor inovador da tradição, usamos a lógica da imaginação para estudá-la. Por meio da arte, recuperamos a vida dos signos porque não temos como não fazê-lo, desde que a nossa tarefa é criar a escrileiturartística de uma Filosofia-Educação da Diferença e não ensiná-la. Assim, em vez do Ensino-da-Filosofia-Verdadeiramente-Verdadeira e da Educação-Que-Todo-Mundo-Já-Sabe-E-Ninguém-Mais-Quer-Saber-Porque-Não-AguentaMais, inventamos uma Filosofia-Experimentação e uma Educação-Da-Filosofia-Criadora. Desse modo, como professoras-pesquisadoras, respondemos positivamente à indagação de Flaubert (apud CAMPOS, 1986, p.5): "Quando é que seremos artistas, nada mais do que artistas, mas realmente artistas"?

Palavras-chave: Filosofia, Educação, Diferença, Escrileituras, Universidade.

\section{Abstract}

Practices, we experience and rehearse reading and writing in the university. By finishing the saturation of the syllogistic, we introduce textual dissonance. Calling for subtle resources and the innovative value of tradition, we use the logic of imagination to study it. Through Art, we recover the life of signs because there is no way of not doing it, since our task is to create the artistic-writreading of a Philosophy-Education of Difference, and not to teach it. Thus, instead of the Philosophy-Teaching-Truly-True and of the Education-That-Everybody-Already-Knows-And-Nobody-Else-Wants-To-Know-Because.

Nobody-Stands-It-Anymore, we created a Phylosophy-Experimentation and an Education-Of-The-Creative-Phylosophy. Thus, as professors/researchers, we answer positively to Flaubert's (apud CAMPOS, 1986, p.5) questioning: "When will we be artists, nothing but artists, but truly artists"?

Keywords: Philosophy, Education, Difference, Writreadings, University.

\section{Determinantes e interstícios}

Em relação à escrita de uma pesquisa, nos cursos de mestrado e de doutorado, há distinções na forma e no conteúdo? Há algo permitido na escrita de uma tese e vedado

Revista Digital do LAV - Santa Maria - vol. 9, n. 2, p. 75 - 100. - mai./ago. 2016 ISSN 1983 - 7348 http://dx.doi.org/10.5902/1983734823514 
na escrita de uma dissertação? Até que ponto a experimentação com a escrita e com o trabalho do pensamento é consentida e encorajada em um e em outro nível dos cursos de pós-graduação? E quando se trata do professor-pesquisador que orienta, escreve e educa, qual será a sua relação com a escrita? Há, nesses diversos níveis, determinantes ou interstícios para uma escrileiturartista na universidade?

\section{Mingau quente}

Sabemos que embora a dissertação seja o ponto culminante do curso de mestrado, também consiste, para um pesquisador universitário, o início de sua vida profissional e intelectual. Podemos dizer que é, aí, no mestrado, ao compor a sua dissertação, mediante a orientação feita por alguém que já possui alguma experiência na pesquisa e na escrita-leitura (escrileitura), que o mestrando exercita a sua condição de pesquisador. Para Marques (2008), a dissertação tem o caráter de iniciação a um tema, sobre o qual ainda não se tem posições definidas.

No mestrado, a pesquisa seria como comer um mingau quente: deve-se começar pelas bordas. Para Marques (2008, p. 138), a abordagem do tema é feita "pelas bordas, buscando delimitá-lo melhor em vistas à continuidade de um processo de pesquisa para cujo domínio teórico e prático justamente se prepara o mestrando" para a continuidade do curso de doutorado. Deste ponto de vista, a autonomia intelectual e a originalidade constituem um ponto de chegada, um resultado a ser adiado durante a realização do mestrado, sendo algo a ser adquirido somente no doutorado.

Já, segundo Kahlmeyr-Mertens (2007, p. 73), a dissertação é um trabalho monográfico aprofundado, na medida em que é a "tematização de um único tema delimitado", fundado em referenciais teóricos constituídos de literatura especializada, com "concatenação lógica de modo ao discurso literalmente dissertar sobre o tema e o problema escolhidos". Ainda que o modo acadêmico de escrita, "que deve ser impessoal e objetivo", caracterizado por "apresentação, discussão e análise de ideias de maneira clara e objetiva" (KAHLMEYR-MERTENS et al., 2007, p. 73), impere em nosso meio, não significa que a forma de expressão de uma dissertação de mestrado, assim como a de uma tese de doutorado, não tenha que ser motivo de preocupação por parte daquele que escreve e daquele que orienta.

\section{Natural e normal}

Podemos divergir da concepção de que, de modo natural, no meio acadêmico, o formato de uma dissertação seria sempre o mesmo, isto é, o dissertativo; de maneira que tal condição não precisasse ser problematizada, pois importaria, exclusivamente, o seu

Revista Digital do LAV - Santa Maria - vol. 9, n. 2, p. 75 - 100. - mai./ago. 2016 ISSN 1983 - 7348 http://dx.doi.org/10.5902/1983734823514 
conteúdo. Contudo, nos é suficiente observar os textos de diversos filósofos para perceber como existem diferentes formas de escrita dentre eles; e, até mesmo, em alguns casos, uma surpreendente variação da expressão, no interior da própria obra de um mesmo filósofo.

Acontece que o movimento de filosofar nunca se deixou tomar pelo monopólio estilístico de alguma escola ou gênero; condição que, em alguma medida, pareceria ser do gosto hegemônico universitário, com a ideia uni-forme de escrita (e leitura) de uma pesquisa. Torres Filho (2005, p. 3), na apresentação da Coleção "Biblioteca Pólen" da editora Iluminuras - a qual pretende semear grãos de antidogmatismo que impedem 0 pensamento de enclausurar-se; e, assim, convidar os leitores à liberdade e à alegria da reflexão -, lembra que, desde a Antigüidade, o filosofar "tem acontecido na forma de fragmentos, poemas, diálogos, cartas, ensaios, confissões, meditações, paródias, peripatéticos passeios, acompanhados de infindável comentário, sempre recomeçado". Tratar-se-ia, portanto, de um recomeço aberto, sem norma, sem natureza nem estilo determinados.

Leminski (1997), em um de seus Ensaios e anseios crípticos, denominado "Forma é poder", critica a suposta "naturalidade na expressão" de um determinado tipo de escrita, presente tanto na academia como no jornalismo. Segundo ele, ambos produziram um discurso automatizado pelo triunfo da razão branca e burguesa, greco-latino-cristão e positivista, a saber: o discurso impessoal, objetivo e natural. Discurso que é investido de normalidade, porque é normal; o qual, por sua vez, provém de norma que é lei: formação de poder.

O que faz a norma senão afirmar a estabilidade do mundo? "De certo mundo, suas relações e hierarquias", responde Leminski (1997, p. 46). Desde que há norma, entretanto, há quem se levante contra ela. Afinal, a norma só é criada para demarcar a sua distinção frente ao anormal e impôr-se à ela. Assim como a norma é uma convenção, o naturalizado modo acadêmico de escrever, claro, neutro e supostamente objetivo, também o é.

Leminski (1997, p.47) compreende que não há como escrever sem a intervenção da subjetividade; ou seja, não há texto sem perspectiva. Ocorre, no entanto, que, no texto pretensamente naturalista (o jornalístico e o acadêmico), "essa perspectiva é camuflada, sob as aparências de uma objetividade, uma Universalidade que - supostamente retrata as coisas 'tal como elas são'".

Alguns leitores poderão dizer que essa argumentação não tem valor algum, pois está apoiada em um poeta livre das grades acadêmicas e que esse perspectivismo de forma e de conteúdo - especialmente de forma de expressão - não tem valor na universidade.

Revista Digital do LAV - Santa Maria - vol. 9, n. 2, p. 75 - 100. - mai./ago. 2016 ISSN 1983 - 7348 http://dx.doi.org/10.5902/1983734823514 
Diante dessa posição, argumentamos que, ainda que o poeta tenha muito a dizer e a ensinar, para aqueles que escrevem na universidade, ele não é o único a afirmar uma posição desconstrutora; já que, no interior da própria academia, há muitos que trilham as mesmas sendas que Leminski.

\section{Risco e divergência}

Também na pesquisa da área de Humanas (Filosofia, Educação, Artes e Literatura), há quem tome a pretensão ao discurso absoluto da objetividade e da clareza como totalitária; assim como há, em todos esses campos de pesquisa, aqueles que se revoltam contra tal pretensão. Verdadeiramente democrática é a obra aberta, aquela que é desautomatizada, que engaja "ativamente, a consciência do leitor, no processo de descoberta/criação de sentidos e significados, abrindo-se para sua inteligência, recebendo-a como parceira e co-laboradora" (LEMINSKI, 1997, p. 48). Temos, aqui, em mente o filósofo, apreciador de literatura e músico Theodor Adorno - autor que aprendeu a pensar com os ouvidos, que realizou e afirmou, na própria escrita, a inseparabilidade entre forma e conteúdo.

É comum, na academia, compreender que o ensaio é feito apenas por aqueles que possuem maturidade acadêmica; isto porque, por meio dele, o pesquisador "toma posição autoral sobre um tema de seu interesse, pautando-se em material de pesquisa, seja ele teórico ou empírico" (KAHLMEYR-MERTENS et al., 2007, p. 74). Desse ponto de vista, um ensaio teria um tom de ineditismo, o qual pode (ou deve) ser alcançado no doutorado.

Entretanto, a concepção de ensaio não é fixa, visto que, para Adorno (2003, p.16-17), o ensaio "não admite que seu âmbito de competência the seja prescrito", uma vez que, insubordinadamente, ele evoca "liberdade de espírito" e ocupa "um lugar entre os despropósitos". Desse modo, a forma ensaística foge à norma e à normalidade, tornando-se arriscada e divergente. Só que, ao contrário do que poderíamos imaginar, a forma ensaística não é exclusiva para os experimentados e experientes escritores.

\section{Esforços do ensaio}

Em seu texto "O ensaio como forma", Adorno ([1954] 2003, p.16) encoraja os jovens pesquisadores a se aproximarem dessa forma de escrita. Segundo o autor, os esforços de um ensaio "espelham a disponibilidade de quem, como uma criança, não tem vergonha de se entusiasmar com o que os outros já fizeram". Ora, não é justamente isso que ocorre com cada mestrando e doutorando que chega aos cursos de mestrado ou de doutorado: entusiasmados e sem vergonha com as ideias de outros?

Revista Digital do LAV - Santa Maria - vol. 9, n. 2, p. 75 - 100. - mai./ago. 2016 ISSN 1983 - 7348 http://dx.doi.org/10.5902/1983734823514 
Em nota de rodapé, Adorno (2003, p.16) apresenta a definição dada por Lukács que contempla a consideração de ser produzido algo novo, mas, no entanto, relacionado com o já formado:

O ensaio sempre fala de algo já formado ou, na melhor das hipóteses, de algo que já tenha existido; é parte de sua essência que ele não destaque coisas novas a partir de um nada vazio, mas se limite a ordenar de uma nova maneira as coisas que em algum momento já foram vivas. E como ele apenas as ordena novamente, sem dar forma a algo novo a partir do que não tem forma, encontra-se vinculado às coisas, tem de sempre dizer a 'verdade' sobre elas, encontrar expressão para sua essência.

Tomamos essa caracterização adorniana de ensaio, na direção de demarcar uma perspectiva alegre e inventiva em relação às heranças filosóficas, artísticas, literárias e científicas que recebemos; visto que, nela, felicidade e jogo são essenciais à forma ensaística, que é sempre aberta a novas interpretações conceituais.

Por meio do ensaio, pensamos ser possível inventar formas de expressão e de pensamento acerca de um objeto inúmeras vezes pensado e expresso (DELEUZE; GUATTARI, 1996). Isso porque o ensaio não busca uma verdade totalizante e final, tal como o método científico pretendeu, desde Descartes; do mesmo modo como a vida também não se determina por regras puramente lógicas e a verdade não é encontrada exclusivamente nos modelos e conceitos unificadores e totalizantes fornecidos pelo método científico (ADORNO, 2003).

Adorno (2003, p.25) afirma que foi somente o ensaio que levantou dúvida em relação ao suposto "direito incondicional do método", isto porque leva em conta a consciência do não-idêntico entre o modo de exposição e a coisa, ainda que não a expresse. Além disso, o ensaio, que tem caráter fragmentário, é avesso à universalização, não se deixando reduzir a um princípio.

\section{Ato de revolta}

Dessa perspectiva, ensaiar é um ato de revolta. Para Adorno (2003, p.25), o ensaio se revolta "contra a doutrina, arraigada desde Platão, segundo a qual o mutável e o efêmero não seriam dignos da filosofia; revolta-se contra essa antiga injustiça cometida contra o transitório, pela qual este é novamente condenado no conceito".

Como resultado de tal revolta, o ensaio dedica-se a acentuar "o parcial diante do total", sendo Montaigne (1980) o grande exemplo dessa postura frente à escrita e ao pensamento. Ao retomar um fragmento de Lukács que elogia o grande ensaísta, em seus Ensaios, Adorno (2003, p.25) diz que Montaigne "abandona suas próprias e orgulhosas esperanças, que tantas vezes o fizeram crer estar próximo de algo definitivo: afinal ele

Revista Digital do LAV - Santa Maria - vol. 9, n. 2, p. 75 - 100. - mai./ago. 2016 ISSN 1983 - 7348 http://dx.doi.org/10.5902/1983734823514 
nada tem a oferecer além de explicações de poemas dos outros ou, na melhor das hipóteses, de suas próprias ideias".

É preciso, pois, desembaraçar o pensamento da ideia tradicional de verdade, para, então, "eternizar o transitório" e unificar, livremente, pelo pensamento, "o que se encontra unido nos objetos de sua livre escolha". Diversamente daqueles que ainda acreditam na possibilidade de alcançar a verdade em si, o ensaio "não insiste caprichosamente em alcançar algo para além das mediações - e estas mediações históricas, nas quais está sedimentada a sociedade como um todo -, mas busca o teor de verdade como algo histórico por si mesmo" (ADORNO, 2003, p. 27).

A Montaigne (1980, p.71) importa que tornemos nossos os saberes alheios e que façamos algo com eles em nossas vidas, em favor delas: exatamente o que ele exercita em seus Ensaios. "Que pensamos?" (dos saberes alheios); e o "que fazemos?" com eles são as preocupações mais relevantes, para Montaigne; caso contrário, "um papagaio poderia substituir-nos", diz ele. Fazendo eco a Cícero, Montaigne afirma: "não basta adquirir sabedoria, é preciso tirar proveito dela"; e realiza a seguinte analogia: "Que adianta ter a barriga cheia de comida se não a digerimos? Se não a assimilamos, se não nos fortalece e faz crescer! [...] Tanto nos apoiamos nos outros que acabamos por perder as forças".

No ensaio, portanto, entram em jogo as experiências individuais de escritas e de leituras daquele que escreve; as quais, por sua vez, são mediadas pela experiência mais abrangente da humanidade histórica - comumente registrada em textos que aguardam a sua ressurreição "à luz do ritual de sucessivas leituras, traduções, interpretações" (LEMINSKI, 1997, p. 29). Trata-se, desse ponto de vista, também em uma dissertação de mestrado - sem ter que esperar o doutorado chegar -, de pôr-se na escritura, não a partir de um "achismo", de uma coleção de opiniões soltas, mas de uma série de escolhas e de relações que cada pesquisador que, necessariamente, torna-se escritor precisa fazer, para que o texto seja efetivamente seu e singular.

Os ensaístas poderão ser acusados de superficialidade? Talvez. Porém, o que importa isso para aquele que experimenta e se arrisca? Estará ele preocupado com acusações desse tipo? Concernirá o juízo de Deus àqueles que experimentam e inventam modos de escrileituras e de existência? (DELEUZE, 1997).

Sabemos, de antemão, que toda divergência implica riscos e acusações, pois, quem disse que a profundidade seja preferível à superfície? Dependendo da perspectiva, podemos tomar o superficial como algo que possui vasta dimensão; enquanto aquilo que tem grande profundidade, como uma superfície fraca. Quem dirá que a primeira não é mais interessante, instigante e potencializadora do que a segunda? Já o poeta e ensaísta

Revista Digital do LAV - Santa Maria - vol. 9, n. 2, p. 75 - 100. - mai./ago. 2016 ISSN 1983 - 7348 http://dx.doi.org/10.5902/1983734823514 
Valéry (apud DELEUZE, 2003, p. 11) afirmou que "o mais profundo é a pele", visto ser ela que determina a fronteira entre o Eu e o Outrem, que se interpõe, separando, o interior do exterior, o Eu de tudo aquilo que o constitui. Desse ponto de vista, haveria algo mais profundo do que a superfície pele-fronteira?

Ainda assim, para os "profundos"1, apesar de o ensaio não se deixar "intimidar pelo depravado pensamento profundo", Adorno (2003, p.26-27) responde: também o pensamento que produz um ensaio é profundo, isto porque ele se aprofunda em seu objeto, "não pela profundidade com que é capaz de reduzi-lo a uma outra coisa". Não há uma "outra coisa", nada mais Ihe interessa senão as mediações históricas "nas quais está sedimentada a sociedade como um todo".

\section{Na escrita e no pensamento}

O pensamento que ensaia é aquele que se dedica ao seu objeto de estudo e se arrisca; quiçá, chega a pensar e a fazer algo por meio da mediação do seu objeto, ultrapassando, assim, o mais baixo nível do pensamento, a recognição (DELEUZE, 1988). O pensamento que ensaia a escrita, e nela se arrisca, compõe-se a si mesmo; na medida em que experimenta, assume sua potência produtiva e se retira do cortejo da origem, pois considera que não há um fim em si ou um dado primordial, uma origem primeiríssima na qual um pensamento sério e genial chegaria. Afinal, atrás de uma máscara há sempre outra máscara; depois de uma caverna outra caverna; textos geram novos textos; pois o que há são interpretações, produções de sentido que cada um encontra nas mediações que estabelece.

Sentido é o que realmente tem relevância, essa "entidade mais misteriosa do universo" que se determina entre a "consciência, a vivência, as coisas e os eventos" (LEMINSKI, 1997, p. 11). Que sentido haveria dedicar tanto tempo de uma vida de leitura e de escrita, que é pesquisa e, em boa medida invenção de si, se não fosse para produzir sentido? (CORAZZA; RODRIGUES; HEUSER; MONTEIRO, 2014). Tirando isso, não tem sentido viver e, menos ainda, viver na academia. A questão é: quão aberta está a universidade para ensaiar a escrita viva, arriscada e divergente? Algumas publicações universitárias (como este Dossiê), algumas dissertações e teses orientadas em (poucas) linhas de pesquisa, estão abertas ao risco, ocorrendo isso mais na Educação e nas Artes

\footnotetext{
${ }^{1}$ A esses respondemos com as palavras de Tournier: "um sentimento como o amor mede-se bem melhor caso possa ser medido - pela importância da sua superfície do que pelo seu grau de profundidade. Porque eu meço o meu amor por uma mulher pelo fato de que amo igualmente as suas mãos, os seus olhos, a maneira como anda, a roupa que usa, os seus objetos familiares, aqueles que a sua mão aflorou, as paisagens onde a vi evoluir, o mar onde se banhou... Tudo isso é bem a superfície, parece-me! Enquanto um sentimento medíocre visa diretamente, em profundidade, o próprio sexo e deixa tudo o mais numa penumbra indiferente" (TOURNIER, 1985, p. 61).
}

Revista Digital do LAV - Santa Maria - vol. 9, n. 2, p. 75 - 100. - mai./ago. 2016 ISSN 1983 - 7348 http://dx.doi.org/10.5902/1983734823514 
do que na Filosofia e na Literatura ${ }^{2}$, para ficar no âmbito do que se convencionou chamar de Humanas. Como diz Bukowski (2016, p.228), algumas escritas da universidade "parecem estar pelo menos escapulindo do século 19 enquanto se aproxima o século 21 . Um indício adorável, de fato".

\section{Abandonar para escapulir}

Para escapulir das malhas dos modos de pesquisar, ler e escrever, como se fosse em séculos passados, e arriscar a escrita viva e divergente, parece imprescindível que sejam abandonados alguns códigos familiares e passadiços da pesquisa em Humanas. Por isso, damos a ver alguns dos abandonos que o campo de Pesquisa em Humanas, feita sob inspiração da filosofia da diferença (que nos mobiliza, especialmente), fez e continua fazendo em nome de um processo de variação contínua levado ao seu extremo; ao ponto de suas forças transbordarem todas as codificações já feitas nesse campo e, às vezes, por alguns, suas escritas serem consideradas incompreensíveis e suspeitas, justamente por seu transbordamento e suas posições transgressoras.

Reconhecemos, é verdade, que as pesquisas feitas em Humanas - com inspiração nietzschiana, deleuze-guattariana, barthesiana, foucaultiana, derridiana, entre outras já produziram textos escritos como pensares, quereres e estares, na condição de projetos, desenvolvimentos ou resultados de pesquisas a partir disso que, agora, abandonaram. Tais abandonos, contudo, se devem ao fato de terem perdido a graça, por não darem mais gosto para os textos e nem mais forçarem o pensamento a encontrar-se com o seu limite. Alguns desses abandonos podem ser encontrados a seguir.

10) O empirismo na pesquisa, que valorizava a experiência no processo de conhecimento; tomava os fatos como critério único, ao qual o pesquisador podia legitimamente se ater; usava o método dedutivo para fazer o transcendente e a razão desaparecerem nas sombras; acrescentava, em seguida, a consciência humana para operar sobre esses fatos e atribuía-lhe a responsabilidade de esclarecer a essência da realidade pesquisada e das suas formas - essência que fornecia o principal sustentáculo à pesquisa e era considerada a causa dos fenômenos sensíveis investigados.

\footnotetext{
2 Há alguns professores e orientadores, em alguns cursos de pós-graduação e de graduação, sensíveis à variação na escrita, incentivadores da invenção de diferentes formas de expressão e de conteúdo, que modificam também a relação com os seus objetos de estudo. Entre outros programas, existem diversas dissertações e teses produzidas pelo LAV - Laboratório de Artes Visuais, da Universidade Federal de Santa Maria, responsável por este Dossiê; assim como pesquisas desenvolvidas, em nível de mestrado e doutorado na Linha de Pesquisa 09 - Filosofias da diferença e educação, componente do Programa de Pós-Graduação em Educação da Faculdade de Educação da UFRGS; além de pesquisas ensaísticas produzidas no Programa de PósGraduação em Filosofia da UNIOESTE, Toledo. Destacamos, ainda, múltiplas experiências de leitura e escritura desenvolvidas (2011-2014) pelo projeto interinstitucional "Escrileituras: um modo de ler-escrever em meio à vida" (UFRGS, UFPel, UFMT e UNIOESTE), apoiado pelo Observatório da Educação CAPES/INEP (CORAZZA; RODRIGUES; HEUSER; MONTEIRO, 2014).
}

Revista Digital do LAV - Santa Maria - vol. 9, n. 2, p. 75 - 100. - mai./ago. 2016 ISSN 1983 - 7348 http://dx.doi.org/10.5902/1983734823514 
$\left.2^{\circ}\right)$ O racionalismo, que submetia a forma de conhecimento fornecida pela pesquisa exclusivamente à razão, e dela derivava um acordo perfeito entre o racional e a realidade; e que funcionava, por meio da evidência das demonstrações e da comprovação das ações do campo das Humanas, considerando-as enquanto primordialmente racionais, em seus princípios, condutas e finalidades; uma pesquisa que analisava, científica ou logicamente, o que chamava de "dados" e privilegiava a capacidade crítica do pesquisador de realizar suas análises por meio do raciocínio.

30) Em terceiro lugar, os textos abandonaram o romantismo, composto por duas faces: a) um romantismo que dotava a pesquisa de exageros afetivos, por destacar as personalidades tanto do pesquisador como dos pesquisados, seus estados de espírito, atitudes, sensibilidade, emoções e valores interiores; que propunha a elevação dos sentimentos ou de ideais utópicos acima do pensamento; que reforçava uma visão de mundo e de educação centrada nos indivíduos, nas subjetividades e no Eu; que enfatizava a liberdade de expressão e de iniciativa, bem como as infinitas chances de auto-realização do pesquisador-professor; que glorificava o particular, o íntimo, o cadaum-é-um; e que propunha um professor-pesquisador divinizado, orgulhoso de sua força individual e vitorioso, capaz de elevar-se sobre os educadores comuns e de afirmar suas ambições e desejos, por meio da mobilidade social; b) por outro lado, um romantismo voltado para a outra face do individualismo, cujos textos eram dotados de uma melancolia espessa, centrados no lado sombrio da existência ou do trabalho dos educadores e no lado inútil ou previamente determinado dos destinos dos seus alunos, cujos gritos confessavam seus sonhos gorados, projetos fracassados, medos e sofrimentos; que traziam um eu oprimido, esmagado pela solidão e pela brutalidade de um mundo burguês, interessado apenas na acumulação de capital. Este segundo tipo de textos românticos desempenhou um papel central naquela pesquisa heróica, que travava combates contra a ignorância e a ideologia, propunha suicídios de classe (média e alta) e conclamava a aquisição de uma consciência libertadora, exclusivamente por amor à revolução, às classes e aos saberes populares.

$\left.4^{\circ}\right)$ Abandonaram, ainda, o realismo em pesquisa, com a sua autoridade de auto proclamar-se veículo de crítica a instituições, em especial, mas também a ideias, a textos, à hipócrita pedagogia burguesa, aos preconceitos, às explorações; com suas exigências da observação rigorosa de objetos ou de personagens do dia-a-dia, da constatação crua das coisas (como o cotidiano do professor, da sala de aula, da escola), ou da adequação da pesquisa a referentes exteriores e a práticas escolares - já que eles e elas sim, continham a verdade da educação. Uma pesquisa que, para reforçar a denúncia social, tinha o cuidado de sempre escrever seus textos numa linguagem clara e

Revista Digital do LAV - Santa Maria - vol. 9, n. 2, p. 75 - 100. - mai./ago. 2016 ISSN 1983 - 7348 http://dx.doi.org/10.5902/1983734823514 
direta, mais coloquial; enquanto se radicalizava rumo a uma objetividade, supostamente sem conteúdo ideológico e era, assim, conduzida ao naturalismo.

$5^{\circ}$ ) Embora os textos possam dizer que abandonaram a pesquisa realista, combinando-a ou colocando-a ao lado da naturalista, havia entre essas pesquisas algumas diferenças, tais como: a) enquanto a realista procurava dar uma visão global daquilo que escrevia, atentando para a vida psicológica dos pesquisados, a pesquisa naturalista atinha-se à vida biológica dos pesquisados, geralmente, para comprovar as teorias (de origem darwinista) que equiparavam o homem, excluída a sua capacidade de raciocínio, a um animal; b) a outra diferença dizia respeito ao espaço social e à classe enfocada, já que o pesquisador realista se voltava preferencialmente para a descrição da educação burguesa, e para os problemas que este modo de educar produziam no indivíduo e no corpo social, o que justificava a sua preocupação com o psicológico articulado ao social; enquanto o pesquisador naturalista, por sua vez, buscava no espaço coletivo (como em escolas ou em espaços não-escolares), com ênfase às camadas pobres da população, a comprovação de suas hipóteses. Unidas, as duas pesquisas privilegiaram cenas cotidianas dos grupos sociais menos favorecidos, compuseram e usaram palavras carregadas para criar textos pesados, tristes, impactantes.

60) Os textos abandonaram também a pesquisa neo-realista e pós-modernista, que resgatava o realismo e o naturalismo, sob fortes inspirações do marxismo, da linguística estruturalista ou da psicanálise freudo-lacaniana; buscava a objetividade como modo de dar credibilidade aos resultados das pesquisas; propunha-se a ser dotada de um forte ativismo político; utilizava uma prosa revolucionária, que tomava posição clara na luta de classes, em favor dos oprimidos, denunciava as desigualdades sociais e os desmandos das elites; ou então se utilizava da liberdade linguística e de um determinado intimismo psicanalítico, existencialista, ou ainda derivado da fenomenologia, no qual a consciência, tanto do pesquisador quanto dos pesquisados, estava posta numa relação ao mundo, que era definida pela intencionalidade, isto é, pelas significações dadas pelos sujeitos às suas circunstâncias.

\section{Posologia da diferença}

Todos esses abandonos ocorreram por meio de certo uso da filosofia da diferença ao pesquisar e, correlatamente, escrever na área de Humanas. Aqui, foi necessário inventar a seguinte espécie de posologia.

1) Não serão usados quaisquer procedimentos de leitura e de escrita integrantes da história da filosofia greco-ocidental, sejam monográficos ou doxográficos; sejam os que

Revista Digital do LAV - Santa Maria - vol. 9, n. 2, p. 75 - 100. - mai./ago. 2016 ISSN 1983 - 7348 http://dx.doi.org/10.5902/1983734823514 
estabelecem uma dualidade entre causa repressora e desejo reprimido; ou que prevêem uma relação entre representante deformador e representado deformado.

2) Não serão feitos resumos de posições doutrinais, recensão de obras particulares, nem apresentação de autores, que dependam de configurações sensíveis e formas categoriais, ou de substâncias qualificadas e posições hermenêuticas.

3) Não se fará qualquer quadro de honra de individualidades, por mais inventivas e brilhantes que se as considere.

4) Não serão escritos nomes de filósofos, mas uma filosofia feita de matéria informada e forças anônimas, partículas e diagramas, hecceidades e phylum, com os quais os estratos de conteúdo e expressão são formados.

5) Os nomes dos filósofos serão índices, indicações de componentes, fios conectores para penetrar na problemática que os ultrapassa, mas da qual eles souberam perceber as possibilidades e também os limites.

6) Quando os nomes próprios forem citados é porque já se terão transformado em assinaturas, isto é, em modos de um invariante constitutivo da problemática tratada.

7) Não se tratará de objetos, cronologia, temas, textos, livros.

8) Dirá respeito a uma problemática e à desmontagem e remontagem de seus agenciamentos maquínicos de expressão.

9) Não se fará exposição em extensão, seguindo teses ou fases de algo chamado obra.

10) Será mostrada a problemática, seu funcionamento e articulação, a sua sintaxe e condições de existência.

11) Melhor dito: o próprio ato de filosofar será mais escrito, descrito, dado a aparecer, como pura função e pura matéria, do que alguma filosofia.

12) Em nenhuma circunstância, se tratará de experiências profissionais ou de reticências pessoais.

13) Não se lidará com espantos fingidos nem com questões já formuladas, venham de análises contrárias ou identificadas com o pensamento trabalhado.

14) Não serão formulados problemas artificiais de coerência doutrinal, e ninguém se auto atribuirá o mérito de resolvê-los.

15) Não existem contradições.

16) Bem como não serão aceitas posições samaritanas, já que ninguém precisa ser salvo de coisa alguma.

17) Está expressamente proibido querer ser mais nietzschiano do que Nietzsche, mais spinozista do que Spinoza, mais deleuziano do que Deleuze.

18) Nunca serão ajustadas contas com algum passado, seja emocional ou intelectual.

Revista Digital do LAV - Santa Maria - vol. 9, n. 2, p. 75 - 100. - mai./ago. 2016 ISSN 1983 - 7348 http://dx.doi.org/10.5902/1983734823514 
19) Não se fará qualquer crítica viciada ou aporética da filosofia, já que o próprio sentido da operação crítica muda.

20) A crítica é primeira, como a própria filosofia.

21) Não se fará crítica representacional, que supõe um objeto e um sujeito em relação de oposição e de exterioridade mútua.

22) Será exercitada a função transcendental da crítica, própria de um pensamento positivado de modo radicalmente imanente.

23) Todos os procedimentos de leitura e de escrita serão, portanto, minoritários; isto é, dotados da qualidade irredutível do impoder (HEUSER, 2016) e ligados ao funcionamento de uma máquina abstrata de expressão.

24) Por toda parte, haverá uma única e mesma paixão de ler e de escrever.

25) Mas não será a mesma paixão, já que as suas linhas abstratas traçam uma variação contínua.

26) Variação contínua que, somente ela, constrói um real por vir, um novo de realidade.

\section{A favor e contra}

A escrileiturartística em Filosofia-Educação posiciona-se contra e a favor de alguns princípios, formas, modos de expressão e de conteúdo. Vejamos, a seguir, algumas posições (para referências bibliográficas completas, consulte CORAZZA, 2008).

I - Contra... o princípio aristotélico da identidade (arte = imitação da natureza); as sínteses ideais, hipostasiadas no Absoluto, no Universal e no Humano; o formalismo nirvânico, a contemplação, as ideias fracas; a geleia geral, a gelatinosa figuração representacional de temas e motivos; a eloquência balofa e roçagante, a sintaxe legitimada, o verso como unidade rítmico-formal; o adjetivo o adjetivo o adjetivo; as epígrafes as epígrafes as epígrafes; as aspas as aspas as aspas; a ABNT; a ideia que duas coisas conjugadas produzem uma terceira (em vez de sugerir alguma relação entre ambas); o pensar discursivo-especulativo e o desenvolvimento harmônico-linear de princípio-meio-fim; o símbolo, o mito, as alusões, o que "há-por-trás?" (advindos da má consciência); a função catártica da escritura e a aquisitiva da leitura; a ossificação dos gêneros e fórmulas (literários, poéticos, acadêmicos); os patrimônios vegetativos e reacionários; o mundo reversível, as ideias objetivadas, cadaverizadas, o stop do pensamento que é dinâmico. O indivíduo vítima do sistema, fonte das injustiças clássicas, das injustiças românticas. E o esquecimento das conquistas interiores; Roteiros. Roteiros. Roteiros. Roteiros. Roteiros. Roteiros. Roteiros.

Contra... a imbecilidade corriqueira e a preguiça domingueira; o descanso remunerado e a senectude dos autores-oficiais; as indigestões de sabedoria, à la Andrade, provocadas

Revista Digital do LAV - Santa Maria - vol. 9, n. 2, p. 75 - 100. - mai./ago. 2016 ISSN 1983 - 7348 http://dx.doi.org/10.5902/1983734823514 
pelos porres-mal-tomados dos eruditos-de-plantão (aplicados, esforçados, participantes, engajados) e a sua omissão diante da mediocridade, da babaquice, da burrice; aqueles que abdicam da crítica (em prol do apoio-a) e o seu conformismo face à ignorância; os resultados (confortadores, consoladores, redentores) de Educadores e Filósofos DeCarteirinha e sua mística (arcaica) de um Pecado-Original atribuído aos Sem-Carteirinha; o sereno, sensato e sem-sabor bom-tom dos escritos-simplórios e a peste metafóricolirificante que os assola; a pseudo-arte de uma juventude senilizada, de precoces candidatos a mestres-doutores, que da-missa-não-sabem-o-terço (até, talvez, por falta de tempo) e acham que o mundo começou quando eles nasceram; a abastança universal de Significação e de Imagens que só repetem o Mesmo; aquele-clima: "é sobre o mar"? então, tem de usar símbolos marítimos, gaivotas, conchas, ondinas, búzios; as regras (em vez do texto-criação) e sua esterilidade pequeno-burguesa; todos os paraísos (doméstico, familiar, institucional, existencialista, político), criados pelas sublimações antagônicas; as escleroses urbanas e o tédio especulativo; o ufanismo dos estados exóticos, mágicos, marginais, malditos; o teatro de tese, as oficinas técnico-literárias, os romances de ideias, a poesia-militante, a escultura-heróica; a solidão medrosa e seus depressivos ápices criativos; a morfinização nostálgica de jogos sem imprevistos e a memória, como fonte de costumes; a ignorância real das coisas + falta de imaginação + sentimento de autoridade ante a prole curiosa; o aviltamento, a inveja, a usura, a calúnia, o assassinato.

Contra... a adesão acadêmica e sua correlata submissão (gozosa) a orientadores, grupos (endinheirados), núcleos, centros, diretórios, comissões, câmaras, pró-reitorias, áreas (reconhecidas), linhas (tradicionais e a distância), coordenadorias, conselhos (da-hora); todos os importadores de consciência enlatada; convênios livrescos, editoriais e derivadas incursões petrificantes, ao gosto-da-moda, do-que-vende, do-que-dá-prêmio; pistas oníricas de subjetivismos inconsequentes, que substancializam objetos nos limbos do inconsciente; o saudosismo individualista dos amantes da fixidez de soluções convencionadas e a inutilidade de suas estéticas insalubres; a narratividade da lógica racional e a dureza de suas estruturas; as asfixias tardo-românticas, o automatismo psíquico, o irracionalismo surrealista, as elucubrações metafísicas e as desconversas im/expressionistas; o tomar as palavras como veículos indiferentes e os olhares oblíquos, dissimulados, de soslaio, a elas dirigidos; o realismo simplista das palavras-mortas e a exploração de sua introspeç̧ão auto-debilitante; sistemas de signos (que se pretendem estruturalmente perfeitos), sua descrição (fiel) das coisas, que veicula (sem deformações) uma visão de mundo (científica, tecnológica, humanista); a melodia na música, a figura na pintura e o discursivo conteudístico-sentimental na prosa do drama

Revista Digital do LAV - Santa Maria - vol. 9, n. 2, p. 75 - 100. - mai./ago. 2016 ISSN 1983 - 7348 http://dx.doi.org/10.5902/1983734823514 
íntimo; a função emotiva, na poesia romântica (do amolecimento ou do soluço): poesia do eu-lírico, de teor biográfico-emocional, exortativa, suplicatória, encantatória, de sentimento pessoal; os fósseis do binômio forma (fôrma)-conteúdo e seus ritmos tradicionais, retrocessos pusilânimes, estéticas solipsistas; o ofuscamento da culturmorfologia (metamorfose vetoriada, transformação qualitativa), em prol de um conforto artístico livre do pânico da invenção; todos os álibis para todas as acomodações de todas as Estéticas de Retaguarda e seus recuos acumpliciadores; meios-termos, meios-caminhos, meias-palavras, meias-verdades, meios-textos, meias pesquisas, meias-vidas; a obra em reflexo (em vez de em-progresso, em-processo), suas dicções paradas ou apenas nuances da própria dicção (em detrimento da variação contínua); intenções sentenciosas (didáticas, proféticas, evangelizadoras), sua pseudo-seriedade e engajamento autocomplacente; a utopia wagneriana da Obra de Arte Total e o pendor romântico-parnaso-simbolista; o prosaico processo analítico, especializado no uso do verbo ser, como cópula entre sujeitos e estados fixos; a farmacopéia ideal do texto, com sua burla, tapeação e falsificação, tão comuns que passam desapercebidas; a ornamentação fantasista (margaridas e passarinhos) e as quantidades de palavras que não funcionam como material de leitura, por não serem necessárias ao entendimento do assunto; os críticos: (a) que praticam a dialética da maledicência; (b) não iluminam nem se deixam iluminar; (c) os desconfiados e os ressentidos com a sua própria incompetência cósmica para entender ou criar alguma coisa de novo; (d) vermina pestilente (Pound), que desviam a atenção dos melhores para os de segunda categoria ou para os seus próprios escritos críticos.

Contra...; texto-bom-moço desinfecto, texto-ressentido, triste, texto-apóstolo, confidente, texto-humilhação, texto-renúncia, texto decorativo, digerível pelos tolos, de tônus místico-idealista, texto de expressão, intimista, de pirotécnicas subjetivas, texto banho-maria, morno, rotineiro, comadre, texto-chá-entre-amigos, texto-prato-feito, requentado, rançoso, texto-a-quilo, texto-retórico, cerebrino e sofisticado, texto-metaartístico, cópia, detalhe naturalista, morbidez romântica, texto-ultra-romântico (hipostasiado na máquina, na criancinha, no cachorrinho), texto-figura-de-tapeçaria, texto-bombástico, texto-sétimo-dia (serve para descansar), texto-finado, que arrasta cadáveres e a melancolia de mortos-vivos, texto-cripta-funerária dos medalhõesempertigados, manequins-pomposos, medrosos-inspirados.

Contra... teses-manifestos; a imbecilidade tacanha dos aspirantes-a-escritores que nunca leem; a fetichização da ideia do novo, nesses tempos de pós-tudo; a realidade social, vestida e opressora, cadastrada por Freud.

A escrileiturartística na Pesquisa em Humanas manifesta-se...

Revista Digital do LAV - Santa Maria - vol. 9, n. 2, p. 75 - 100. - mai./ago. 2016 ISSN 1983 - 7348 http://dx.doi.org/10.5902/1983734823514 
II - A favor... da realidade sem complexos, sem loucura, sem prostituições e sem penitenciárias do matriarcado de Pindorama; do novo: (a) como processo de recuperação viva e crítica do passaturo; (b) já que a apreensão do novo representa a continuidade e a extensão da nossa experiência do que já foi feito, e nesse sentido quanto mais nós compreendemos o passado, melhor nós entendemos o presente; de todas as heranças (que dão-o-que-pensar) e a concomitante responsabilidade de assumi-las como coisa viva e não como ritual mortuário, o que implica colher no ar uma tradição viva; da ampliação dos nossos repertórios (visto que todo presente de criação propõe uma leitura sincrônica do passado de cultura), para: (a) recuperar o que há de vivo e ativo no passado; (b) saber discernir, na mole abafante de estereótipos que é um acervo artístico visto de um enfoque simplesmente cumulativo; (c) os veios de criação, patentes ou ocultos; (d) sobretudo estes, marginalizados por uma incompreensão historicizada; do conhecimento do-que-foi-feito: a melhor maneira de nos prepararmos para entender oque-não-foi-feito e o-que-se-pode-fazer-de-novo; da crítica (com suporte de um plano de pensamento) que contribui para melhorar aquilo que critica, como: (a) a crítica via comparação e tradução; (b) a crítica de iluminação contra a crítica de maledicência; da escrileitura inventiva de traduções-recriações (traduzir sob o signo da invenção; tradução-criativa, recriação, transcriação) de textos criativos, que funcionam autonomamente e reeditam os achados formais do original, nas quais: (a) o poeta que traduz - ou melhor, transcria - um poema clássico leva, de saída, uma vantagem considerável sobre o erudito não-poeta que translada o mesmo texto; (b) onde só ser possível traduzir poesia através da transposição criativa; (c) reimaginar, preferível ao conceito usual de traduzir; (d) traduzir é uma ginástica com a palavra: um trabalho de perfeccionismo. Algo que nunca assume o aparato estático do definitivo, mas que permanece em movimento, tentativa aberta e constante, trazendo sempre em gestação novas soluções, pistas novas, que imantam o tradutor, obrigando-o a um retorno periódico ao texto e seus labirintos; (f) a tradução se torna uma espécie de jogo livre e rigoroso ao mesmo tempo, onde o que interessa não é a literalidade do texto, mas, sobretudo, a fidelidade ao espírito, ao clima, frente ao diverso feixe de possibilidades do material verbal manipulada; da beleza do texto, não como um ornamento aplicado, mas o que faz a imagem mental mais definida; da alegria ativa de ler e da liberdade vital para escrever; dos erros criativos e da higienização dos mitos; do minimalismo (das textificações, texturas, contextos, texturações); de ser raro e claro; da desaparição elocutória do poeta e da reaparição espectral de um eu desfigurado e sem-saída; de uma teoria da composição: (a) que não abole o acaso, mas o incorpora como termo ativo, ao processo criativo; (b) opção criadora, portanto, que significa liberdade de escolha; (c)

Revista Digital do LAV - Santa Maria - vol. 9, n. 2, p. 75 - 100. - mai./ago. 2016 ISSN 1983 - 7348 http://dx.doi.org/10.5902/1983734823514 
mas, acima de tudo, liberdade vigiada por uma consciência seletiva e crítica; (d) de modo que, sobre o enxame de constelações móveis, atuam certos critérios de seleção e descarte; (e) impondo balizas (formantes) à pura fermentação do acaso; da criação de nossos próprios objetos textuais (passa a não ter importância o fato de as palavras não serem um dado objeto, porque, na realidade, elas serão sempre o objeto dado).

A favor... da correlação, continuidade e permeação (honestas) de percepções e ações da Pesquisa em Filosofia-Educação com diversas manifestações artísticas; do barroco, simultaneísmo, dadaísmo, futurismo, cubismo, arte negra, pop-art, arte ready made, música pós-dodecafônica; das reivindicações dos Manifestos: (a) Poesia Pau-Brasil (1924); (b) Antropófago (1928); (c) Futuristas (Fundação, 1909; Técnico, 1912), que proferem: (a) é preciso destruir a sintaxe, dispondo os substantivos ao acaso de seu nascimento; (b) empregar o verbo no infinitivo, para que se adapte elasticamente ao substantivo e não fique submetido ao eu do escritor; (c) abolir o adjetivo, para que o substantivo nu mantenha sua cor essencial; (d) abolir o advérbio, fivela velha que mantém unidas as palavras num conjunto; (e) orquestrar as imagens, dispondo-as a partir de um máximo de desordem; (f) Nada de pontuação; (g) Depois do verso livre, eis, enfim, as palavras em liberdade; da Semana de Arte Moderna e das marcas modernistas (1922 são os 10 dias que abalaram o mundo na literatura brasileira, renovação da crítica literária (anos 40,50), novo teatro, cinema novo, bossa-nova; dos romances-invenções, romancepoema, Bildungsroman, nouveau roman, romance-cíclico, romance-rio, romance-cinematográfico, romance-Vita-Nova; da poesia pau-brasil (1924), a nossa primeira mercadoria de exportação: A síntese. O equilíbrio. O acabamento de carrosserie. A invenção. A surpresa. Uma nova perspectiva. Uma nova escala. A língua sem arcaísmos, sem erudição. Natural e neológica. A contribuição milionária de todos os erros. Como falamos. Como somos; da poesia-bumerangue-concreta (anos 50 e 60, ao redor da revista paulista Noigandres) e suas ações com: (a) o material (em pé de igualdade com os restantes elementos de composição); (b) e a estrutura espaciotemporal (a qual suscita, no campo de relações, estímulos óticos, acústicos e significantes); (c) adquirindo assim, com o mundo total de objetiva atualidade, um parentesco isomórfico; (d) que é furtado, desde o treinamento infantil; (e) e nos prende num campo de símbolos substantivos; de poesia objetivista, visual, holopoesia, videopoesia, computer poetry (70 aos 80 ), eletrônica (90); de toda poesia de transição, poesia de guerra, poesia carro de assalto; da profusão de recursos gráficos e tipográficos (pontuação, caligrama, ideograma, desenhos, fontes, posição e direção livre das linhas, espaços brancos, usos da folha, cores, substituição da pontuação por sinais musicais, etc.); da inter-ação do verbal, da inelutável modalidade do visível e do audível, num

Revista Digital do LAV - Santa Maria - vol. 9, n. 2, p. 75 - 100. - mai./ago. 2016 ISSN 1983 - 7348 http://dx.doi.org/10.5902/1983734823514 
breve espaço de tempo através de um breve tempo de espaço; da estruturação verbivocovisual de palavras dúcteis, moldáveis, amalgamáveis, em suas andaduras escorreitas: gráfico-espacial, acústico-oral e conteudística; da humana aventura e da terrena finalidade.

A favor... da porosidade da leitura e do assédio-moral da escritura; da palavra texto: (a) que é também texto mesmo, enquanto conteúdo, isto é, enquanto objeto designado; (b) palavra-texto, que é a coisa-da-coisa, o texto-do-texto (como la mer dans la mer); (c) palavra-texto e coisa-texto como isomórficas, ou seja, conflito de fundo-e-forma em busca de identificação; do texto que não quer dizer nem-isto-nem-aquilo, apenas diz-se a si próprio; do texto que é idêntico a si mesmo e daquele que se assemelha só à dessemelhança do autor; do texto feito de palavras-e-silêncios, difícil, mas útil, consumível, a ser usado; da demolição da ideia (corrente) que um bom-texto tem de ser chato: Necessitamos de uma ciência da literatura que pese Teócrito e Yeats numa mesma balança, e que julgue os mortos enfadonhos tão inexoravelmente como os enfadonhos escritores de hoje, e que, com equidade, louve a beleza sem referência a almanaques; da fantasia imagética (sem fios) das obras em-processo e do fluxo polidimensional (sem fim) das obras em-progresso; da atomização da linguagem, elipse de temas periféricos, organização circular, estrutura pluridividida e capilarizada dos textos; da qualificação rigorosa, forma aberta, sintaxe experimental, novo sistema de equilíbrios entre partes e novas relações de vizinhança e hierarquia; de um todo-textual que, mais do que a (gestáltica) soma das suas partes, é diferente e vive em tensão (pop e anárquica) com as singularidades parciais; da vivificação da facticidade da palavra, como campo magnético de novos possíveis; da desintegração de palavras e descoagulação dos blocos de ideias; da concentração, simplicidade e condensação; de palimpsestos, collages, associações sonoras, narrações simultâneas, ritmos de palavrascoisas nos espaços-tempos (abstraídos); dos movimentos de pontos-eventos, mecânica qualitativa, estrutura dinâmica, arquitetônica e neoplasticista da poesia-prosa e da prosa-poética.

A favor... da linguagem sintética, substantiva, direta e comunicativa, e estruturalmente consequente; das composições breves: tensão músculo-linguagem, elementarismo contundente, ginástica para a mente entorpecida no vago, obra-prima do óbvio e do imediato atirada à face rotunda da retórica; dos novos saberes e das novas emoções; das aventuras criativas; da experiência humana poetizável, da presentificação dos acontecimentos e de toda mentação; da tensão em direção ao infinito de formas, dissonâncias e trucagens; da figura do escrileitor factivo, que trabalha rigorosamente a obra, como um operário da construção civil ergue um muro; de desregramento e

Revista Digital do LAV - Santa Maria - vol. 9, n. 2, p. 75 - 100. - mai./ago. 2016 ISSN 1983 - 7348 http://dx.doi.org/10.5902/1983734823514 
nutrimento de impulsos (aléficos) para expansões, fruições e relâmpagos de palavras que morrem-e-nascem e de teses-manifestos que se transformam.

\section{Aforismos de escrita}

Abandonos, distanciamentos, posições e a favor e contra, posologias aqui e acolá nos encaminham para um funcionalismo artistador da leitura e da escritura em Educação, Filosofia, Ciência, Artes... Vejamos alguns aforismos que daí podem resultar acerca de escrever "Como um cão".

Festa. - A escrita faz do pensar uma festa? - Mas, se não nos enganamos, na universidade, quase não há festa! - Tão morta que é uma tristeza! - Por isso mesmo!

De brincadeira. Brincar de escrever, usando a intensidade zero do desejo de pesquisar e educar como catapulta. Despojar a escrita dos seus elementos representativos ou emocionais. Desmontar os modelos incorporados às palavras, que as levam a realizar movimentos figurativos e a imitar alguém ou alguma coisa. Constituir um movimento novo e puro de escrita, que extraia do escrever como evento a sua energia. Brincar de escrever que tão-somente inventa e devém muitas escritas, abre o seu espaço a todas as espécies de eventos que aí podem ter lugar, a elementos que são heterogêneos, mas que se afectam cada um a todos os outros.

Ensina-se a escrever? - A: É possível ensinar a escrever? - B: Não sabemos se podemos ensinar a escrever. - C: Para Nietzsche (2003, p.144), junto à oratória, a escrita é uma arte que não pode ser adquirida sem "a orientação mais minuciosa e a aprendizagem mais penosa". - A: Agora, dizer, ao modo de Deleuze (1988), - Vem, escreve comigo, implica escrever para ou com os alunos?

Para escrever é preciso ler... - Como Nietzsche (1995, p.47-48) mostrou, essa máxima não é válida para todos os casos. Muitas vezes, para escrever é preciso deixar de ler, é preciso defender-se da mera reação à leitura, subtrair-se a situações e relações em que se fica sujeito a suspender a iniciativa e tornar-se apenas reativo. Aquele erudito que, "no fundo não faz senão 'revirar' livros" perde "totalmente a faculdade de pensar por si". Ou seja, se não revira muitos livros, ele não consegue pensar; se apenas critica, aprovando e reprovando o que já foi pensado, "ele próprio já não pensa", só reage aos pensamentos lidos. O seu instinto de autodefesa encontra-se embotado, pois, se assim não fosse, ele "se protegeria dos livros". O erudito é um leitor em ruínas, um fósforo que se necessita riscar para que brilhe, isto é, para que emita supostos pensamentos - um décadent, no sentido nietzschiano.

Revista Digital do LAV - Santa Maria - vol. 9, n. 2, p. 75 - 100. - mai./ago. 2016 ISSN 1983 - 7348 http://dx.doi.org/10.5902/1983734823514 
O que é. Uma escrita que cria um mundo incerto e perigoso é a única força que faz o professor-pesquisador diferenciar-se, isto é, tornar-se o que ele é, para além do que dele foi feito.

Contramão. Para escapar de uma escrita indiferenciada, que vale para tudo, e afirmar radicalmente a diferença de uma escrileiturartista, importa investi-la de uma não-relação com a prática e de afectos da Natureza. Então, ela será apreciada justamente por estar saturada destes afectos e por não ter qualquer semelhança com aquela prática. Tudo isso na contramão do moralismo otimista do amor pedagógico.

Escrevo sempre diferente de mim. Escrever de um modo que não seja fusão, projeção, nem identificação com ninguém implica afirmar um princípio de diferenciação no próprio interior da escrita, que aspira à exterioridade absoluta. Assim como dizer: Porque sou algo diferente de mim, porque estou sempre no exterior de mim mesma, é que escrevo diferentemente de mim. Será essa diferença a única que me permite entrar num processo de devir-escritora, como ser singular, real, que me torna outra? Talvez, uma educadora-escritora?

Como um cão. Ao artistar a escrita em Humanas, tomamos partido rigoroso contra qualquer escrita nostálgica, redentora, aconselhadora, messiânica, profética. Ao escrever, bebemos de fontes vivas. Uma necessidade de escrever nos persegue como um cão.

Combinações. Pode-se pensar a escrileiturartista em Humanas como uma grandeza determinada e um número determinado de centros de força. Disso se segue que ela tem de passar por um número calculável de combinações, no grande jogo de dados da existência do educador. Em um tempo infinito, cada combinação possível está alguma vez alcançada, infinitas vezes. Cada uma dessas combinações expressa o mundo das Humanas que infinitas vezes já se repetiu e joga seu jogo in infinitum.

A obra. Essa escrita, com seu caráter de simulacro, é singularidade que perturba a realidade da educação e que melhor representa o seu pensamento como jogo afirmador do acaso. Ela escava o campo da moralidade e da religião, as motivações inconfessáveis que estão na origem dos valores éticos pretensamente absolutos, a valorização da racionalidade científica. Afirma, então, uma ciência alegre, o luxo intelectual e a filosofia dos espíritos livres, que celebram o corpo, os instintos e a Terra.

Esquecimento. Ao escrever, nos esquecemos, por momentos, do mundo dos estados de coisas, embora a este mundo estejamos fadados. Renovada, nossa escrita se desinteressa de qualquer benefício, prestígio, divulgação, opõe-se à ordem natural, e liga-se à morte, que é condição da vida. Ela se assume como uma escrita mal-dita. E,

Revista Digital do LAV - Santa Maria - vol. 9, n. 2, p. 75 - 100. - mai./ago. 2016 ISSN 1983 - 7348 http://dx.doi.org/10.5902/1983734823514 
gloriosa, ousa, imagina, cria problemas, como faz todo aquele que artista, ao invés de resolver problemas. É desse modo que combate a angústia e o desgosto.

Estilo. A escrileiturartista liga-se a uma prova, a uma seleção, como objeto da vontade e da liberdade. Repete-se a própria escrita, fazendo dessa repetição o objeto do escrever, aquilo que encadeia a escrita, salva e cura a repetição do Mesmo e da Lei Moral. Há, nela, ao mesmo tempo, todo um jogo místico de perdição e de salvação, de morte e de vida, de doença e de saúde. Além de toda uma potência, "que é a da repetição do eterno retorno" (DELEUZE, 1988, p.28).

Escrita-esquizo. $\grave{A}$ escrita-representacional pergunta-se: - O que quer dizer? $\grave{A}$ escrileiturartista: - Como funciona? Nos dois tipos de perguntas, existem mundos diferentes. De um lado, encontra-se uma escrita da qual faz-se exegese ou justificação, algo cognitivo, uma lógica do conhecimento extra-perspectivista. De outro, uma escrita para a qual valem apenas funcionamentos posicionais no mesmo complexo educacional, renúncia a qualquer interpretação, opção exclusiva pela utilização operatória. Maquinação de uma escrita, que é somente produtiva, nem expressiva nem representativa. Privilegiamento de uso; produtividade em relação à expressividade; utilização operatória em detrimento do sentido exegético. Perseguição de uma lógica da invenção. Escrita que não sai da razão, mas renova a arte do pensamento ao reenviar "o pensamento para a arte" (RAJCHMAN, 1991, p.58).

Desmembrado. É preciso afectar e ser afectado para poder escrever. Escrever é ser desmembrado. É metamorfose constante. É abertura de um futuro que nunca começou. Errância total.

Um caso. - A: Escrever tem a ver com o que se viveu ou se vive. - B: E se não se viveu e nem se vive nada que valha a pena ser escrito? - C: Como assim? Todo mundo vive; logo, todo mundo escreve. - D: Só que escrever é um "caso de devir", "sempre inacabado, sempre em vias de fazer-se", é um processo, "uma passagem de Vida", que "extravasa qualquer matéria vivível ou vivida" e "atravessa o vivível e o vivido" (DELEUZE, 1997, p.11).

Viver. Escrever é um pensamento de vida, não uma receita de felicidade, nem uma sonolência gostosa, ou uma irresponsabilidade divertida. Profundo vitalismo: os modos de vida inspiram maneiras de pensar e escrever; os modos de pensar e escrever criam maneiras de viver. A vida ativa o pensamento e a escrita; o pensamento e a escrita afirmam a vida. Como fazer da escrita uma arte de viver? Como torná-la vivível? Como criar uma unidade entre vida ativa e escrita afirmativa? Escrever é dobrar o Fora, como faz o navio com o mar. Fazer do pensamento uma experiência do Fora, escapar do senso comum, desestruturar o bom senso, entrar em contato com uma violência que nos tira

Revista Digital do LAV - Santa Maria - vol. 9, n. 2, p. 75 - 100. - mai./ago. 2016 ISSN 1983 - 7348 http://dx.doi.org/10.5902/1983734823514 
da recognição e nos lança diante do acaso, abalando certezas e o bem-estar da verdade. Perder as referências conosco e com o mundo exterior, afastar-nos do princípio da realidade, romper com as referências cognitivas, promover uma ruptura com a doxa, colocar em dúvida o próprio pensamento, o Divino, o Verdadeiro, o Belo, o Bem. Escrever é criar, aligeirar e descarregar a vida, inventar novas possibilidades de vida, fazer nascer o que ainda não existe, ao invés de representar o que já está dado e admitido.

O Fora. Aquele que escreve sob a pressão do Fora, do deserto, do exílio, vê fragmentarse a própria unidade subjetiva e desaparecer a forma da interioridade de qualquer essência do Eu. Então, aquele Fora-de-Si, que diz "Eu escrevo", não pode representar um sujeito, não pode ambicionar um Eu idêntico a si mesmo, porque integra uma linguagem sem sujeito atribuível. As mãos que escrevem não são dele, nem de ninguém, muito menos de algum autor, que nada mais é do que um sujeito inventado. Elas escrevem uma escrita anônima, despersonalizada, liberta das garras de qualquer sujeito desaparecido no discurso. Então, só há um ser: o ser da linguagem que habita o espaço literário, prenhe de um eterno movimento (BLANCHOT, 1987). Quem escreve? Ora, um Desdobrado, cuja palavra passa a constituir um espaço de transgressão, em que tudo o que é fixo se torna móvel, as verdades são abaladas e vêem-se desmanchadas as dicotomias interior/exterior, sujeito/objeto, eu/mundo. Esplendor de um escrevinhador impessoal...

As forças. Enquanto o tempo do mundo é infinito, não teve início nem terá fim, as forças da escrileiturartista, embora múltiplas, são finitas, presentes em toda parte. Forças que só existem no plural, que não são cada uma em si, mas somente na relação com outras, e que não são alguma coisa, mas um agir sobre outras forças. Não se pode dizer que elas produzem efeitos nem que se desencadeiam a partir de algo que as impulsionam, porque implicaria distingui-las de suas manifestações e enquadrá-las nos parâmetros da causalidade. Elas tampouco podem não se exercer porque isso seria atribuir-Ihes intencionalidade e enredá-las no antropomorfismo. As forças dessa escrita simplesmente se efetivam, irradiando vontades de potência, agindo sobre outras, resistindo a outras, querendo estender-se até o limite, manifestando um querer-vir-aser-mais-forte, o que explicita o seu caráter intrínseco à escrita mesma.

Teoria materialista. Fazer uma teoria materialista da escrita é: 1) expressar um mundo possível; 2) pôr eventos a bailar; 3) desmascarar a mediocridade e a compaixão; 4) denunciar a crueldade, a hipocrisia e o ressentimento; 5) execrar o prosaísmo, a vulgaridade e o tédio; 6) perguntar pelo valor dos valores; 7) transvalorar a moral tradicional que habita as Humanas.

Revista Digital do LAV - Santa Maria - vol. 9, n. 2, p. 75 - 100. - mai./ago. 2016 ISSN 1983 - 7348 http://dx.doi.org/10.5902/1983734823514 
Teoria-prática. Na concepção da escrileiturartista, não há distinção entre teoria e prática: a escrita não é uma teoria sendo feita sobre a prática, que cobiçaria atingir a sua essência, descobrir as suas leis, ou reduzi-la a seus conceitos. Nada há para ser conhecido em alguma instância metafísica "A prática"; nada há que possa transcender essa prática e tomá-la como objeto; não há, lá, nenhum sujeito, nenhuma identidade permanente, nenhum sentido por trás dela, nenhum fiador universal ou olhar divino, nenhuma substância inalterada por trás dos sucessivos acidentes, que seja suporte de diversos atributos; nenhuma prática, enfim, que seja fundamento para a escrita. O que tomamos como "fato", criado pela escrita, é sempre já resultado da atividade cognitiva e interpretativa humana. Por isso, a escrileiturartista não vai deixar de ser, também ela, uma forma de esquematização da prática, introduzida por um "sujeito", ou seja, pela necessidade prática e vontade humana de falsificar o mundo, de impor formas ao que é disforme, de simplificar o que é complexo, de regular o que é caótico, de dar sentido ao que é sempre não-senso, de criar o Ser no que não conhece outro estado senão o do devir.

Ficção. Todo conhecimento conceitual ou categorial produzido por essa escrita é uma ficção reguladora, não tem valor de verdade, mas é relativo, interpretativo e antropomórfico. Só pode ser assim, já que todo conhecimento não é uma verdade ontológica - mesmo que esta fosse apreendida por meios intuitivos -, mas estritamente operatório.

Imanência. A escrileiturartista integra uma doutrina da imanência.

Contingência. Cada texto é fragmentado e parcial; mas a escrileiturartista em si não seria dada por sua soma, já que esta soma é contingente, encontra-se em devir permanente, enquanto sua perspectiva está continuamente se modificando.

Fluxo. Eternamente movente, maximamente diferenciada, heterogênea, incontável, inumerável, a escrileiturartista é um vir-a-ser que não deriva de um estado anterior e nunca atinge um estado final. Ela carece de medida, fundamento e finalidade. Ela é acaso, contingência e necessidade. Caso fortuito, delírio, pathos da distância. Fluxo do acontecer, continuum infinito de pontos de vista, força singular de experimentação do alargamento de horizontes.

Maneirismo. A escrileiturartista é uma maneira de escrever, nem mais avançada ou progressista ou evoluída ou científica ou lógica ou natural ou erudita do que as outras escritas. Ela não sublima, não cura, não suspende a vontade, o desejo, o querer... Só que ela sabe rir, comover, mover pernas e asas...

Faxina. A escrileiturartista não é nunca simples. Ela não normatiza, não representa, não conta história, não ilustra nem narra o que se passou. Algo passa por ela. Traços, riscos,

Revista Digital do LAV - Santa Maria - vol. 9, n. 2, p. 75 - 100. - mai./ago. 2016 ISSN 1983 - 7348 http://dx.doi.org/10.5902/1983734823514 
setas, marcas de espírito nela se exprimem e arrancam a significância do texto. De qual texto? Ondas, cascatas, olhos de ciclones, as palavras desse texto não correspondem a formas, mas só captam forças, que se exercem na folha em branco. Em branco? De jeito nenhum; pois, se assim fosse, o escritor poderia reproduzir um fato exterior, que funcionasse como matriz da escrita. Uma folha nunca está em branco, à espera de ser preenchida. Uma folha está, desde sempre, cheia! Povoada de muitos clichês, opiniões, imagens, lembranças, fantasmas, significantes. Por isso, o escritor-artista é um faxineiro: ele esvazia, raspa, escova, limpa (DELEUZE, 2002). Ele escreve sobre os códigos, palavras de ordem, regimes de signos, para rechaçá-los, embaralhá-los, invertê-los, subvertê-los. No entanto, ele distingue entre o que lá pulula: aquilo que favorece a escrita, o que a obstaculiza, aquilo que a bloqueia, o que deixa passar intensidades. Porque ele sabe que, se apenas desmanchar reativamente o que encontra na folha, engendrará outros clichês; os quais, como cabeças de hidra, renascerão enquanto paródias, plágios, achados: "Tanta gente toma (...) um plágio por uma audácia, uma paródia por um riso, ou, ainda pior, um miserável achado por uma criação" (DELEUZE, 2002, p.92). Portanto, é entre a cópia e a criação que o escritor faz marcas: livres, acidentais, irracionais, involuntárias, ao acaso. Agora, essas marcas podem não dar em nada, estragar a folha, não eliminar os dados. Acontece que o escritor sabe o que quer fazer, mas não sabe como fazê-lo, nem no que vai dar. Uma questão de maneiras de pensar e de modos de agir: artistagens da vida...

\section{Ainda-não e póetica}

As pesquisas em Humanas, assim como as concebemos ensaisticamente, na medida em que são compostas experimentando-se, têm uma "intenção tateante" e são tentativas de "acertar na mosca", mesmo que conscientes da sua "própria falibilidade e transitoriedade" (ADORNO, 2003, p. 35). Nas tentativas falíveis e transitórias, como a vida, importa que, com nossas pesquisas, e a partir delas, sigamos ensaiando a escrita na universidade com o ainda-não. Ou seja, o ainda-não experimentado, o ainda-não desejado, o ainda-não pensado, o ainda-não amado, o ainda-não pesquisado, o aindanão escrito, o ainda-não abandonado. Mas, quem sabe um dia ou uma noite...

Cientes de que a temática da escrita na universidade será sempre geradora de conflitos e que, por sua importância vital para a academia, ela retornará ad infinitum, suspendemos, por ora, nossa intervenção, interrompendo-a de forma poética, porque não poderia ser outra.

\section{Estamos fartas das pesquisas comedidas}

das pesquisas bem comportadas.

Revista Digital do LAV - Santa Maria - vol. 9, n. 2, p. 75 - 100. - mai./ago. 2016 ISSN 1983 - 7348 http://dx.doi.org/10.5902/1983734823514 
Das pesquisas de burocracia pública e privada com prazos estabelecidos expedientes protocolos roteiros introdução desenvolvimento conclusão.

Estamos fartos das manifestações de preço e de apreço às pesquisas feitas nos programas de pós-graduação em Humanas com notas 6 e 7 da Capes, às metodologias consagradas, às normas da $A B N T$, aos relatórios do CNPq.

Estamos fartas das pesquisas que param e vão averiguar nos dicionários o cunho vernáculo de um vocábulo.

Abominamos os pesquisadores puristas, continuistas e oportunistas, que pesquisam e escrevem a mesma coisa durante a vida inteira. Abaixo todas as suas palavras de ordem convencionais universais, sobretudo suas gramáticas semânticas sintaxes políticas e linguisticamente corretas.

Abaixo todos os seus ritmos sobretudo os quantificáveis em tantos mil caracteres com ou sem espaço com ou sem referências bibliográficas. Estamos fartas das pesquisas denunciadoras

Descritoras
Salvadoras
Raquíticas
Sifilíticas
Científicas
Medíocres
Do cotidiano
De gestão
Banais
Triviais
Tolas
Burras

De todas as pesquisas que capitulam ao que quer que seja fora de si mesmas.

De resto não são pesquisas-escrituras.

Serão contabilidades tabelas de co-senos exigências do Sistema exemplares de mil modelos de pesquisa que se podem encomendar na internet e maneiras iguais

Revista Digital do LAV - Santa Maria - vol. 9, n. 2, p. 75 - 100. - mai./ago. 2016 ISSN 1983 - 7348 http://dx.doi.org/10.5902/1983734823514 
de agradar os órgãos de fomento, a Qualis, os homens do ministério

e as revistas $A 1$ e $A 2$.

Queremos antes as pesquisas loucas, as pesquisas dos clowns e dos esquizofrênicos.

Queremos as pesquisas pungentes dos bêbados, as pesquisas de fígados cambaleantes e de almas não menos ébrias.

Queremos as pesquisas

cujos júbilos não menos tóxicos

derretem a pesquisa palatável.

Não queremos mais saber de pesquisas que não sejam libertação de

A Pesquisa em Humanas.

A partir de nossas fantasias,

de algumas escrituras que já chegaram e de muitas outras que estão por vir, só queremos pesquisas que,

por favor,

sejam scripturires.

\section{Referências}

ADORNO, Theodor. O ensaio como forma. In: ADORNO, Theodor. Notas de Literatura I. Tradução Jorge de Almeida. São Paulo: Duas Cidades; Ed. 34, 2003.

BLANCHOT, Maurice. O espaço literário. Tradução Álvaro Cabral. Rio de Janeiro: Rocco, 1987.

BUKOWSKI, Charles. Escrever para não enlouquecer. Tradução Rodrigo Breunig; Editado por Abel Debritto. Porto Alegre: L\&PM, 2016.

CAMPOS, Augusto de. O anticrítico. São Paulo: Companhia das Letras, 1986.

CORAZZA, Sandra. Os cantos de Fouror: escrileitura em filosofia-educação. Porto Alegre: Sulina; EDUFRGS, 2008.

CORAZZA, Sandra M.; RODRIGUES, Carla G.; HEUSER, Ester M.D.; MONTEIRO, Silas B. Escrileituras: um modo de ler-escrever em meio à vida. Educação e Pesquisa, v. 40, n. 4, 288p., out./dez. 2014, p. 1029-1044.

DELEUZE, Gilles. Diferença e repetição. Tradução Luiz Orlandi e Roberto Machado. Rio de Janeiro: Graal, 1988.

DELEUZE, Gilles. Crítica e clínica. Tradução Peter Pal Pélbart. São Paulo: Ed. 34, 1997.

DELEUZE, Gilles. Lógica do sentido. Tradução Luiz Roberto Salinas Fortes. São Paulo: Perspectiva, 2003.

Revista Digital do LAV - Santa Maria - vol. 9, n. 2, p. 75 - 100. - mai./ago. 2016 ISSN 1983 - 7348 http://dx.doi.org/10.5902/1983734823514 
DELEUZE, Gilles. Francis Bacon: lógica de la sensación. Tradução Isidro Herrera. Madrid: Arena Libros, 2002.

DELEUZE, Gilles, GUATTARI, Félix. Mil platôs: capitalismo e esquizofrenia. v.2. Tradução Ana Lúcia de Oliveira e Lúcia Cláudia Leão. Rio de Janeiro: Ed.34, 1996.

HEUSER, Ester Maria Dreher. Do poderoso eu ao "impoder" essencial do pensamento: Gilles Deleuze, um começo para pensar. Revista Sul-americana de Filosofia e Educação (RESAFE), n. 25, nov/2015-abr/2016. Disponível em: <http://periodicos.unb.br/index.php/resafe/article/view/17494/12526>.

KAHLMEYER-MERTENS, Roberto et. al. Como elaborar projetos de pesquisa: linguagem e método. Rio de Janeiro: FGV, 2007.

LEMINSKI, Paulo. Ensaios e anseios crípticos. Curitiba: Posigraf, 1997.

MARQUES, Mario Osorio. Escrever é preciso. Petrópolis: Vozes, 2008.

MONTAIGNE, Michel. ENSAIOS I, XXV, "Pedantismo". In: MONTAIGNE, Michel. Ensaios. Tradução Sérgio Milliet. São Paulo: Abril Cultural, 1980.

NIETZSCHE, Friedrich W. Ecce homo: como alguém se torna o que é. Tradução Paulo César de Souza. São Paulo: Companhia das Letras, 1995.

NIETZSCHE, Friedrich W. III Consideração Intempestiva: Shopenhauer educador. In: NIETZSCHE, Friedrich W. Escritos sobre educação. Tradução, apresentação e notas de Noéli Correira de Melo Sobrinho. Rio de Janeiro: PUC-Rio; São Paulo: Loyola, 2003. p.138-222.

RAJCHMAN, John. Lógica do sentido, ética do acontecimento. In: ESCOBAR, Carlos Henrique (Org.). Tradução Ana Sacchetti. Dossier Deleuze. Rio de Janeiro: Holón Editorial, 1991. p. 56-61.

FILHO, Rubens Rodrigues Torres. Biblioteca pólen. In: DERRIDA, Jacques. A farmácia de Platão. Tradução de Rogério Costa. São Paulo: Iluminuras, 2005.

TOURNIER, Michel. Sexta-feira ou Os limbos do Pacífico. Tradução Fernanda Botelho. São Paulo: DIFEL, 1985.

\footnotetext{
' Doutora em Educação pela Universidade Federal do Rio Grande do Sul, Brasil (2008) Professora Adjunta da Universidade Estadual do Oeste do Paraná, Brasil.

ii Doutora em Educação pela Universidade Federal do Rio Grande do Sul, Brasil (1998) Professor Titular da Universidade Federal do Rio Grande do Sul, Brasil.
}

Enviado em: 30 de maio de 2016.

Aprovado em: 01 de agosto de 2016.

Revista Digital do LAV - Santa Maria - vol. 9, n. 2, p. 75 - 100. - mai./ago. 2016 ISSN 1983 - 7348 http://dx.doi.org/10.5902/1983734823514 